\title{
THE FREE MOVEMENT OF SERVICES AND THE RIGHT TO NON- DISCRIMINATION
}

\author{
Raya ILIEVA \\ “Neofit Rilski” South-Western University Blagoevgrad, Bulgaria \\ raiailieva@abv.bg
}

\begin{abstract}
The present article will explore the free movement of services, which is one of the four fundamental freedoms of the citizens of the European Union. The reader's attention will be drawn to the violation of the right to non-discrimination in view of the unfavourable treatment of Bulgarian citizens in comparison with citizens of the European Union regarding the prices of package holidays on the Bulgarian Black Sea coast offered by Bulgarian travel agencies.
\end{abstract}

\section{Keywords: the free movement of services, the right to non-discrimination}

\section{Introduction}

One of the main goals of the European Union as envisaged in Article 25, para 2 of the Treaty on the Functioning of the European Union [1] (TFEU) is the creation of a common or internal market, which is to ensure the free movement of goods, people, services and capital. The same provision defines the internal market as an area without internal borders, in which free movement is guaranteed.

On the one hand, the service sector is of vital importance to the economy of the European Union because it generates more than half of the gross domestic product, on the other, more than half of the economically active population is employed in it.

The present article will be devoted to the free movement of services, which is one of the four fundamental freedoms of the citizens of the European Union. The reader's attention will be drawn to the violation of the right to non-discrimination in view of the unfavourable treatment of Bulgarian citizens in comparison with citizens of the European Union regarding the prices of package holidays on the
Bulgarian Black Sea coast offered by Bulgarian travel agencies. The main goal of the author is to present arguments for the unvafourable treatment of Bulgarian citizens in comparison to European Union citizens when using the same services at the same time and place with the sole difference being the price of the package holiday and the citizenship of the persons using it.

\section{The Free Movement of Services}

According to the provision of Article 4, para 1 of the Tourism Law [2], the persons providing tourism services at tourist sites are obliged to announce the same prices for all tourists and differential treatment of tourists or putting certain tourists into a more unfavourable position is inadmissible pursuant to Article 4, para 1 of the Law on Protection against Discrimination [3] .

The provision of Article 4, para 1 of the Law on Protection against Discrimination regulates a comprehensive, imperative and unconditional prohibition of all forms of discrimination. The prohibition of discrimination concerns the exercising and the protection of all freedoms and rights 
stipulated in the Constitution and the laws of the Republic of Bulgaria, i. e., it is applicable to all spheres of public life (Article 3, para 1 and Article 6 of the Law on Protection against Discrimination). The prohibition applies to all legal persons (Bulgarian and foreign citizens as well as stateless persons on Bulgarian territory, juridical persons and civil associations) and the protection from all forms of discrimination is the same regardless of the sphere it is applied in - employment, education, provision of services, health care, etc [4]. The text of Article 4, para 1 also lists the discrimination grounds: sex, race, nationality, ethnic origin, citizenship, origin, religion or belief, education, opinions, political belonging, personal or public status, disability, age, sexual orientation, marital status, property status and others. According to para 2 of the same article states that „direct discrimination shall be any less favourable treatment of a person on the grounds referred to in paragraph 1 than another person is, has been or would be treated under comparable circumstances". The list includes all grounds stipulated in Article 6, para 2 of the Constitution, while also adding several as expressly envisaged in the directives of the EU [5] .

The prohibition of discrimination is also contained in the regulation of Article 18 of TFEU, which stipulates that any form of discrimination on the grounds of citizenship shall be prohibited. This freedom is guaranteed and is incongruous with the discrimination between the member states and their citizens.

Article 50 of TFEU envisages 4 possible ways to provide services:

1. The person providing the service crosses the state boundary (e. g., legal services);

2 . The person receiving the service leaves his country of residence (e. g., tourism services);

3. Both parties remain in their respective countries - „movement" of the services themselves (e. g., various types of mobile communication services);

4. Both parties leave their countries and provide/receive the service in a third country.

In addition to the above the Court has stated in its judgement in Joined cases 286/82 and 26/83, Luisi and Carbone v Ministero del Tesoro that the freedom to provide services also means freedom to receive services (e. g. tourism services) [6]. In particular, the ,services“ include:

- activities of an industrial character;

- activities of a commercial character;

- activities of craftsmen;

- activities of the professions.

Comprehensive prohibition of the restrictions on the free provision of services and a requirement for nondiscrimination - pursuant to Article 50, para 3 of TFEU the person providing the services may perform his activities temporarily in the country where the service is provided under the same conditions the latter requires from its citizens. The guiding principle applied hereto concerns the equal treatment of local and foreign citizens.

This regulation is further developed in the practice of the Court of Justice of the European Communities. In its judgement in the case Van Binsbergen (33/74) the court rules that ,the restrictions to be abolished pursuant to Articles 49 and 50 of TFEU include all requirements imposed on the person providing the service by reason in particular of his nationality or of the fact that he does not habitually reside in the State where the service is provided, which do not apply to persons established within the national territory or which may prevent or otherwise obstruct the activities of the person providing the service".

In the same judgement the Court points out the direct applicability of the treaty regulations, which gives concerned parties the right to invoke them before national courts in order to oppose all forms of discrimination against the person providing 
the service on the grounds of citizenship or country of residence in a member state other than the member state where the service is provided.

In its practice the Court of the European Union elaborates that the prohibition pursuant to Articles 49 and 50 of TFEU includes not only the direct but also the indirect (actual) discrimination - e. g., when the legal framework seems to apply equally to local and foreign services but in practice is more complicated with regard to the services imported from another member state. In a number of judgements the Court takes into consideration criteria related to the prohibiton of discrimination in the free movement of goods due to the similarity to the regulations of Article 30 of TFEU.

Pursuant to Article 6 of the Constitution of the Republic of Bulgaria no restriction of rights or privileges are admissible, which are based on the grounds of race, nationality, ethnic origin, sex, origin, religion, education, opinion, political affiliation, personal or social status or property status. This regulation is further developed in Article 3, para 4 of the Law on Protection against Discrimination, which states that refusal to provide tourism services at tourist sites as well as providing tourism services of lower quality or at unfavourable conditions shall not be permissible pursuant to the criteria of Article 4, para 1 of the Law on Protection against Discrimination.

With this regulation the state has introduced the right to non-discrimination for persons as a fundamental and protected right [7]. The protection of these rights is ensured by the means envisaged by the law. When they are infringed, the harmed parties have the right to protection. Therefore, every person has the right to equal treatment.

Despite the whole range of laws and measures for protection from discrimination our state still tolerates unequal or differential treatment of
Bulgarian citizens in comparison to citizens of the EU. It is not a secret that booking a holiday through a foreign travel agency costs considerably less than booking through a Bulgarian one. In recent years many of our compatriots have been booking their holidays through foreign tour operators but now such bookings are often refused on the grounds that Bulgarian citizens should book their holidays through Bulgarian travel agents.

The above statement can be proved by the following offers for the period 11-17 August 2014:

\begin{tabular}{|c|l|c|}
\hline Tour operator & Hotel & $\begin{array}{c}\text { Price in } \\
\text { EUR } \\
\text { per } \\
\text { person }\end{array}$ \\
\hline $\begin{array}{c}\text { Sunway Travel } \\
\text { Group } \\
\text { Irish tour } \\
\text { operator }\end{array}$ & $\begin{array}{c}\text { CHAYKA BEACH } \\
\text { RESORT HOTEL } \\
\text { Sunny Beach }\end{array}$ & \\
\hline ASTRAL \\
Holidays BG \\
$\begin{array}{c}\text { Bulgarian tour } \\
\text { operator }\end{array}$ & $\begin{array}{c}\text { CHAYKA BEACH } \\
\text { RESORT HOTEL } \\
\text { Sunny Beach }\end{array}$ & 1046.69 \\
\hline $\begin{array}{c}\text { Opodo Germany } \\
\text { German tour } \\
\text { operator }\end{array}$ & Mirage Hotel 4 stars & $\mathbf{5 1 3 . 0 0}$ \\
\hline Balkantourist & Mirage Hotel 4 stars & 562.40 \\
\hline
\end{tabular}

The package price includes 6 days' accomodation, all inclusive, swimming pool use including deck chair and sunshade, tourist tax and insurance.

One of many cases of discrimination in the Republic of Bulgaria happened in January 2013 when a female Bulgarian citizen tried to book a summer holiday on the Bulgarian Black Sea coast through a Romanian tour operator because offers of the latter cost less than those of the local travel agencies. Unfortunately the woman received a reply from a Bulgarian tourist company, a partner of the Romanian one, which stated that her booking could not be accepted since she did not have Romanian citizenship and the offer in question was only valid on the Romanian market. This is discrimination on the grounds of 
citizenship. The woman submitted a case before the Commission for Protection against Discrimination [8].

\section{Conclusion}

It is a fact that Bulgarians pay more for holidays in Bulgaria than the average British, Romanian or Russian citizen. I think that the establishment of common regulations for tourist packages will contribute to the abolishment of such obstacles and therefore to the creation of a common market for services as stipulated by European and national law. In this way the tour operators based in one member state will have the opportunity to offer their services in other member states and the consumers in the EU will receive the same conditions when purchasing tourist packages in any member state.

The de lege ferenda proposal foresees that the Commission for Protection against Discrimination should initiate enquiries, inter-alia, in the tourism industry and, if necessary, make the relevant suggestions and duly note their importance for the protection of Bulgarian consumers and the influence of the differences in the legal frameworks of the member states on the correct functioning of the common market.

\section{References}

* Lecturer in scientific major "Civil and Family Law" at Faculty of Law and history of South-Western University "Neofit Rilski”" - Blagoevgrad, Bulgaria.

[1] Promulgated OJ C 115, 9.05.2008

[2] Promulgated State Gazette No. 30/26.03.2013, supplemented SG No. 109/20.12.2013

[3] Promulgated State Gazette No. 86/30.09.2003

[4] Gencheva, Z. http://justicedevelopment.org

[5] Directive 2006/123/EC, Directive 2006/54/EC, Directive 2004/113/EC, Directive 2002/73/EC, Directive 2000/78/EC and Directive 2000/43/EC

[6] http://lex.bg/bulletin/?isu=171\&tp=sf\&id=93; In another judgement the Court has stated that receiving professional education is equal to receiving services (wherein professional education includes tertiary education and 1 year of professional training).

[7] Ivanov, A., Stanin, M. Protectability of the right to non-discrimination, Norma, 2013, No. $10,22-26$

[8] Case 136/2013, criterium citizenship, defendant Astral Holidays 